\title{
SHEDDING LIGHT AT THE COALFACE: THE USE OF SOCIO-LEGAL MATERIAL IN LABOUR LAW TEACHING
}

\author{
Amanda ReILLY*
}

\section{INTRODUCTION}

Work is fundamental to commerce and to everyday life. It follows that everyone who works or employs workers would benefit from understanding the relevant law. Indeed, for some professional groups, such as employment lawyers, human resource managers and union organisers, a detailed and in-depth knowledge of labour law is essential. Because of the importance of labour law, the subject is widely taught in undergraduate degree courses in universities throughout Australia and New Zealand in both law and business schools.

There seems little doubt that labour law should be taught. ${ }^{2}$ But how it should be taught is another question. In general, it appears

* Dr Amanda Reilly is a Lecturer in Law in the School of Accounting and Commercial Law, Victoria University of Wellington, Wellington, New Zealand. The author would like to acknowledge and thank Kathryn Sutherland and Meegan Hall, who provided guidance on the survey design and general encouragement, and Claire Angliss, who worked on the project as a research assistant.

1 In Canada and the United States, there appears to be a clear distinction between 'labour' law - that is, the law pertaining to industrial relations and collective bargaining - and 'employment' law, which is underslood as the law relating to individual employment relationships. In Australia and New Zealand, these terms tend to be used more interchangeably. Importantly, for present purposes, in Australia and New Zealand, introductory undergraduate courses (well textbooks) generally cover both aspects. Therefore, here, the term 'labour law' should be understood to encompass both the regulation of unions and collective bargaining and the law relating to individual employment relationships.

2 Although, it must be acknowledged that there is ongoing debate in academic literature regarding the future and relevance of labour law, particularly in the light of the worldwide decline in unionisation: see Harry Arthurs, 'Labour Law after Labour' (Research Paper No 15/2011, Osgoode Hall Law School, Comparative Research Paper Series, 2011) for a concise, recent overview of the debates in this area. There also appears to have been some decline in labour law teaching in the northern hemisphere. For a Canadian view on this, see Brian Etherington, 'Teaching Labour and Employment Law in a Canadian Law School' (Paper presented at the International Association of Law Schools General Assembly Conference on Labour Law and Labour Markets in the New World Economy, Faculty of Law, University of Milan, 22 May 2010) 5. But see Riclard A Bales, 'A Data Driven Snapshot of Labor and Employment Law Professors' (2011) $56 \mathrm{St}$ Louis University Law Journal (forthcoming) <http://ssrn.com/abstract=1789702> for a report on a survey suggesting that, in the United States, while labour law teaching (in the sense of the law pertaining to unions and industrial relations) is in decline, employment law teaching is experiencing modest growth. 
to be widely accepted in the literature that an approach which incorporates socio-legal material is desirable. This is true both for law students ${ }^{3}$ and for students who study some law as part of completing a business degree. ${ }^{4}$ Very likely, this is because labour law is an academic discipline with close connections to other disciplines, such as labour history, industrial relations and economics. It is also a highly politicised subject area, in which there are multiple competing perspectives and interests. To fully understand labour law, it is necessary to have some awareness of the complex policy choices which underpin it, such as the need to find an optimal balance between individual and collective rights. It is also necessary to understand that the law has an impact not only on individuals but also on the economy.

However, while the literature appears to be unanimous on the importance of incorporating socio-legal material into labour law teaching, it is by no means certain that this approach is universally adopted by those who work at the coalface of teaching. It may also be that there are those who would like to incorporate some socio-legal material into their teaching but who are unsure of how best to do this. This article is intended to shed some light on these uncertainties.

This article is divided into three parts. Part II summarises academic debate on how law should be taught, and advances pedagogical and policy justifications for utilising socio-legal material in law teaching in general, and labour law in particular. Part III describes an online survey which invited labour law teachers to comment on their views and their use of socio-legal content in their teaching. The survey findings suggest that a gap exists between the apparent consensus in the literature that socio-legal material is a necessary part of labour law teaching and the practice of some

${ }^{3}$ See, eg, Richard Johnstone, 'Improving Student Learning in Labour Law' in Richard Mitchell (ed), Redefining Labour Law: New Perspectives on the Future of Teaching and Research (Centre for Employment and Labour Relations Law, 1995) 238, 247; Margaret Wilson, 'The New Industrial Law in New Zealand and its Impact on the Construction and Teaching of Industrial Law Courses' in Richard Mitchell (ed), Redefining Labour Law: New Perspectives on the Future of Teaching and Research (Centre for Employment and Labour Relations Law, 1995) 220, 224; Andrew Stewart, 'Teaching Labour Law: Choices and Challenges' in Richard Mitchell (ed), Redefining Labour Lonv: New Perspectives on the Futtre of Teaching and Research (Centre for Employment and Labour Relations Law, 1995) 201; S Willborn, 'Labor Law without Labor' [1988] Wisconsin Law Review 547, 549; W McLeod, "The Importance of Traditional Labor Law in the Legal Curriculum' (1993) 43(1) Journal of Legal Education 123; E Dannin, 'Teaching Labor Law within a Socioeconomic Framework' (2004) 41 San Diego Law Review 93; Joellen Riley, 'Teaching Labour Law in a Common Law Jurisdiction' (Paper presented at the International Association of Law Schools General Assembly Conference on Labour Law and Labour Markets in the New World Economy, Faculty of Law, University of Milan, 22 May 2010) 4.

${ }^{4}$ David Doorey, Harry and the Steelworker for Teaching Labor Law to Non-Law Students) (4 February 2008) Social Science Research Network, $15<$ hitp://ssrn. com/abstract=1089168>. 
labour law teachers. Part IV discusses methods by which sociolegal material may be incorporated into labour law teaching, giving examples drawn from the author's own practice.

\section{How Should Law Be Taught?}

\section{A Two Possible Approaches to Teaching Law}

The teaching and learning of law can happen at a number of levels. A student can learn a specific legal concept embodied in a statute or in cases, and learn how to apply the concept to hypothetical factual situations. Engagement in this sort of activity could be characterised as exemplifying a 'black letter law' approach to teaching and learning law. However, law does not operate in a vacuum; it is always underpinned by context. Concepts from other disciplines, such as sociology, philosophy or economics, may illuminate aspects of the law. In this article, this type of material is termed socio-legal material.

The distinction between these two approaches is shown by the following example, taken from New Zealand labour law. Teaching students the wording of the Employment Relations Act 2000 (NZ) $\mathrm{s} 6$, assigning cases to read on its interpretation, and giving students problem questions to practise applying $\mathrm{s} 6$ is as a black letter law approach. Giving students a historical overview of the Employment Relations Act, and suggesting that its introduction could be seen as a logical outcome of the New Zealand Labour Party's historical affiliation with the Union movement, is a socio-legal approach.

Twining famously identified two competing ideals of legal education - the 'Plumber' and 'Pericles'. The 'Plumber' view is that legal education should be viewed primarily as training for a trade. Such an education focuses strongly on practical vocational training, with an emphasis on mastery of technical black letter law. By contrast, the 'Pericles' ideal of legal education is broad and liberal. Twining suggests that the qualities a 'Pericles' education should seek to develop are: 'intellectual discipline, detachment, breadth of perspective, an interest in human nature and a capacity for independent and critical thought'.6 Socio-legal materials extrinsic to the legal doctrine, as exemplified in cases and statutes, would clearly have a place in such a curriculum but would be much less relevant to those operating with a 'Plumber' concept of legal education.

While opinions may vary as to the need for socio-legal content in legal education, it seems uncontroversial that a certain amount of black letter 'Plumber' content must form part of a program of legal study. The study of law, by its very definition, must have some

5 William Twining, Law in Confext: Enlarging a Discipline (Oxford University Press, 2002) 63, which reproduces a lecture delivered in 1967.

6 Ibid. 
reference to legal doctrines, cases and statutes. Both law and business students expect that their curriculum will contain a certain amount of substantive law and that this will be of use in their future careers.

The place of socio-legal material in law teaching, and the need for a 'Pericles' approach in educating law students, has been the subject of ongoing debate in the academy. Stuckey et al suggests that:

Generations of debate have not resolved the relative merits of a liberal, general education versus a technical, professional orientation for the practice of law. ${ }^{?}$

By contrast, the literature concerning undergraduate business law teaching, in business schools, appears to reflect some degree of consensus that it is not appropriate to teach business students using a strictly black letter law approach. ${ }^{8}$ The reasons for this include that business students may find pure black letter law boring, and that they require a broad understanding of the implications of law on business rather than detailed technical knowledge of specific laws.

Across subject areas where law is taught to non-lawyers a consensus emerges from published literature that the aim is not to create legal experts ... [Rather] the focus is on ... enabling [students to understand] the practical application of legal principles, to see the relevance of law and the often contested nature of its genesis, and to become sufficiently curious to research further.

The approach suggested for business students is thus more akin to a 'Pericles' approach than a pure black letter 'Plumber' approach.

Regardless of any controversy about the place of socio-legal material, New Zealand universities are, by statute, supposed to be concerned primarily with advanced learning. Their principal aim is stated to be developing intellectual independence. ${ }^{10}$ Universities are also required to accept their role as conscience and critic of society. ${ }^{.1}$ This requirement appears significant within an Australian context too. ${ }^{12}$

Law teaching, at least in Australian and New Zealand universities, should reflect these imperatives. Students learning law at universities

${ }^{7}$ R Stuckey et al, Best Practices for Legal Education: A Vision and a Road Map (Clinical Legal Education Association, 2007) 17.

8 Doorey, above n 4, 15; V Allen, A Reflection on Delivering Legal Education to Business Students (United Kingdom Centre of Legal Education, 2006).

$9 \mathrm{~S}$ Braye, $M$ Preston-Shoot and $\mathrm{R}$ Johns, 'Lost in Translation? Teaching Law to Non-Lawyers: Reviewing the Evidence from Social Work' (2006) 2 Law Teacher $121,139$.

10 Education Act 1989 (NZ) s 162(4)(a)(i).

11 Ibid s 162(4)(a)(v).

12 The Australian Universities Commission, Sixth Report (Australian Government Publishing Service, 1975) stated that 'one of the roles of a university in a free society is to be the conscience and critic of that society', quoted in P Karmel, 'Funding Universities' in T Coady (ed), Why Universities Matter (Melbourne University Press, 1998) 165. 
should receive more than a technical training in the substance of the law. They should also learn to see law within its broader context and, as a corollary, develop the intellectual independence to critically evaluate it. This is especially so for students studying labour law, given the centrality of work to society and to individuals.

\section{B Justifications for Incorporating Socio-Legal Content into Labour Law Teaching}

While preparing students for professional legal practice is a concern for law schools, many students (both law and business) who study labour law will never practise as labour lawyers. However, most, if not all, will work and many will be employers or managers responsible for the safety and wellbeing of their subordinates. They will also all be consumers and voting citizens in a democracy; some will become involved in representative government. Each of these roles requires choices about personal conduct and the treatment of others - in the workplace; when purchasing goods manufactured in countries known to have fair work standards; or when deciding whether to vote for one party rather than another on the basis of its labour policies. As bodies charged with a duty to develop intellectual independence and act as 'critic and conscience of society', universities should equip students to fulfil these roles, and make these choices, in an informed and reflective manner. ${ }^{13}$ Studying labour law in its sociolegal context is an excellent vehicle for achieving this. It imparts not just basic knowledge of the law but an understanding of why the law exists and the purposes that it is intended to serve. The socio-legal approach also helps to develop the intellectual tools with which to formulate views on the need for law reform.

Even from a strictly vocational perspective, there is a danger in focusing solely on substantive content at the expense of socio-legal context. In 2000, the Australian Law Reform Commission made the following observation:

[A] requirement that students must 'master' (or at least 'know') large bodies of substantive law ignores the stark reality that this substance changes dramatically over time - sometimes in a very short time. ${ }^{14}$

There is no doubt that rapid change has been a feature of labour law as a subject area in New Zealand and Australia. Australia, in particular, has been through a decade of tumultuous change with Workplace Relations Act 1996 (Cth), amended by the Workplace Relations Amendment Act 2005 (Cth), only to be superseded by the Fair Work Act 2009 (Cth). New Zealand's labour law legislation

13 Education Act 1989 (NZ) sI 62(4)(a)(v).

14 Australian Law Reform Commission, Managing Justice: A Review of the Federal Civil Justice System, Report No 89 (1999) 150 [2.83]. 
has been relatively static since the introduction of the Employment Relations Act 2000 (NZ). However, this Act represented a dramatic change in the law from the previous Employment Contracts Act 1991 (NZ).

The recommendation made by the Australian Law Reform Commission applies to labour law educators generally:

Accompanied by a commitment to facilitating 'lifelong learning' for professionals [labour law educators] might consider adoption of an underlying philosophy which holds that [i]n a changing environment, the best preparation ... is one which promotes intellectual breadth, agility and curiosity; strong analytical and communications skills; and a (moral/ ethical) sense of the role and purpose of [labour law]. ${ }^{15}$

To prepare students in this way, it is surely necessary to incorporate some reference to the underlying socio-legal context of the law in a labour law course.

In addition, there are pedagogical justifications for incorporating socio-legal material into labour law teaching. Richard Johnstone cogently summarises important rescarch findings in educational literature and, drawing on the work of Marton and Saljo, among others, suggests that a key aspect of improving students' learning has to do with their 'approach to learning'. ${ }^{16}$ Students who adopt a surface approach to learning do not try to make sense of the subject matter they are learning as a whole but instead 'focus on unrelated concrete and literal aspects of the task'. ${ }^{17}$ They may, for example, focus unreflectively on trying to memorise the elements of a legal rule. By contrast, students who adopt a deep approach to learning 'organise and structure the subject matter into a coherent whole'.' Students relate components taught in one course to their learning in other courses, and to their personal experience and knowledge of the world more generally. Deep approaches to learning 'result in high quality, well structured and complex outcomes, an enjoyment of learning, a commitment to the subject and ... imaginative and adaptive skills." 19 Labour law teachers can make such learning possible by introducing socio-legal material to their teaching, thereby providing opportunities for students to make the connections between labour law and its surrounding context.

15 lbid 153 [2.89], citing D Weisbrot, 'From the Dean's Desk' (1994) 3(1) Sydney' Lanv School Reports 1 .

16 Marton and Saljo first developed the concepts of deep and surface learning: $F$ Marton and R Saljo, 'On Qualitative Differences in Learning - Outcome and Process' (1976) 46 British Journal of Educational Psychology 4-11. This early work has subsequently been built on by others, notably Ramsden: see P Ramsden, Learning to Teach in Higher Education (Routledge, 1992); and Biggs: see, eg, J B Biggs, 'Teaching for Better Learning' (1991) 2 Legal Education Review 133.

17 Johnstone, above n $3,239$.

18 Ibid 240.

19 Ibid. 
Arguably, a policy of teaching labour law within its socio-legal context is more conducive to active learning. Educational researchers have emphasised for decades that active methods of learning are more effective than passive ones. ${ }^{20}$ Incorporating some socio-legal material into labour law teaching can help students to engage in higher-level thinking, beyond mere memorisation and application of law. This approach equips students to engage in synthesis, as they incorporate the principles of the law into its surrounding context and their own knowledge-base. This ultimately gives them a wider perspective from which to evaluate the law.

In summary, incorporating some socio-legal material into labour law teaching is conducive to the following outcomes:

(a) Creating an environment in which students can learn to see law within its broader context and develop the intellectual independence to evaluate it critically. This is in keeping with both a 'Pericles' approach to teaching law and with the role that universities are expected to fulfil in developing intellectually independent learners and as the conscience and critic of society.

(b) Creating an environment conducive to deep learning and active learning.

The following part discusses the author's research into the use of socio-legal materials by labour law teachers in Australia and New Zealand.

\section{The SurveY}

\section{A Method}

The goal of the author's research was to identify how labour law teachers incorporate socio-legal material into their labour law teaching and, at the same time, to canvas their views on using sociolegal material. For the purposes of this research, 'socio-legal' was defined as any content which is not doctrinal black letter law; for example, the historical or political context of the law, economics, political theory, feminist theory, or concepts drawn from industrial relations and human resources.

The survey was designed to elicit from participants their views on the importance, or otherwise, of socio-legal material in teaching labour law, as well as to gain a picture of the ways in which such material is incorporated into teaching. A short online survey was prepared using the online survey software Qualtrics - an abbreviated version of the questionnaire can be found in Appendix A. The choice was made to use an online survey because it would be possible to reach a larger number of labour law teachers throughout universities in Australia and New Zealand.

20 Stuckey et al, above n 7, 388. 
In accordance with University ethics approval, the survey was configured to be anonymous; it did not track names, email or IP addresses. Consent to participate in the research was implied by completion of the survey.

One reason for anonymising responses was to encourage frankness. While the relevant legal literature appears to reflect a consensus that socio-legal material should be used in labour law teaching, this is not necessarily reflected in the views and teaching practices of those at the coalface of teaching undergraduate labour law. It was hoped that anonymity would make it easier for respondents to express any dissenting views.

A research assistant was charged with looking through university websites throughout New Zealand and Australia to identify where labour law courses were taught. There were some difficulties with this, as not all universities update their course offerings on their websites regularly and the relevant information was not always easy to locate. Ultimately, 27 courses were identified as fitting within the definition of undergraduate degree courses in labour law. Nineteen of these were located in law schools and were aimed at law students, while eight were aimed specifically at business students. Suitable potential participants, associated with labour law courses, were identified through university websites or through personal contact with the researcher.

Once suitable participants were identified, they were contacted by email and invited to complete an online survey. The survey was intentionally short, recognising the many time demands on academic staff. It was hoped that the brevity of the survey would result in a higher response rate.

A range of questions were asked to gain some insight into the following broad research questions:

(a) 'How important do labour law teachers in Australasia consider socio-legal material to be in their teaching?' To answer this research question, labour law teachers were explicitly asked to rate how important they considered incorporating socio-legal material. Respondents were also asked some questions aimed at teasing out how much weight socio-legal material was given within their courses.

(b) 'How is socio-legal material incorporated into labour law teaching in Australasia?' In order to answer this question, respondents were asked to identify what sort of socio-legal material they referred to in their teaching. Respondents were also asked to identify what techniques they used to incorporate this material in their teaching. 


\section{B Limitations of Research}

It must be acknowledged that the research described above was a small-scale project which focused exclusively on undergraduate labour law degree courses in Australian and New Zealand universities. The study also did not include postgraduate or post-experience programs (such as MBA courses), or labour law courses taught at non-university educational institutions.

Forty Australian and New Zealand academics were identified as having some interest in labour law and all were invited to complete the survey. This included those who were obviously currently associated with a suitable undergraduate course, as well as those who appeared to be active in research in the area. It seemed likely that active researchers might have some involvement in teaching the subject. Respondents were asked to choose one labour law course which they were either previously or currently involved in to focus on for the purposes of the questionnaire. If respondents were involved in teaching a labour law course as part of a team, they were asked to give their best estimate of the course in its entirety rather than focusing solely on their own contribution. Thirteen respondents completed the survey. Twelve of these were currently teaching an undergraduate labour law course and one bad taught such a course in the past. Because some courses are team taught, the survey was sent to more than one person at some institutions (five in total), it is not possible to state with certainty that each response represents a different labour law course. Nonetheless, the response rate provides sufficient data to give some insight into the views and practices of Australian and New Zealand undergraduate labour law teachers.

That said, it must also be acknowledged that the research may represent a biased sample. Those teachers with no interest in using socio-legal material may simply have elected not to take the survey. A further limitation of the study is that, as this was an online survey, respondents' views could not be probed. As such, the results provide a snapshot of respondents' views, but these have not been explored as fully as they may have been if some other methodology had been utilised. Nonetheless, respondents did have the opportunity to raise any comments they wished at the end of the survey; a number chose to do this. 


\section{Findings on How Important Labour Law \\ Teachers Consider Socio-Legal Materials}

As discussed above, an apparent consensus exists in the labour law education literature that socio-legal material should be incorporated into labour law teaching. When asked how important they considered this, it is not surprising that, of the 13 respondents, seven (54 per cent) reported that they thought it was "extremely important to refer to socio-legal content in teaching the labour law'. Five considered it somewhat important ( 38 per cent).

One respondent was of the view that:

A student cannot understand this area without a broader socio-political context.

However, another respondent considered it to be 'not very important' and commented as follows:

I teach in a law school and I teach employment law, which is a combination of common law, statutes, and case law interpreting the statute and the purpose is to enable the law grad to represent employers, employees, and unions with individual and collective employment relationship problems.

This suggests that there are at least some teachers who adhere to a 'Plumber' perspective on legal education as a form of technical training for legal practice.

While one can gain an impression of the extent to which sociolegal material is valued by asking respondents how important they feel it is, their actual practice, as they describe it in the questionnaire, is also revealing. Respondents were asked the question, '[i]s there any reference, whether formally or informally to socio-legal content in the teaching of the labour law course you are focusing on for the purposes of this survey?' The answers indicated that 11 out of 13 respondents (that is, 85 per cent) incorporated socio-legal material into the course that they had chosen to focus on for purposes of the survey. However, two respondents ( 15 per cent) reported that they did not incorporate any socio-legal material into their teaching at all. This seems to indicate that there is a gap between the apparent consensus in the literature that labour law should be taught in a manner incorporating socio-legal material and the teaching practice of some teachers.

On a side note, while the literature suggests that law and business teachers might approach incorporating socio-legal material into labour law teaching differently, ${ }^{21}$ the survey findings do not support

21 Doorey, above n 4, 11; Stewart, above n 3, 217-19. 
this. In fact, the findings did not indicate any significant difference between law and business teachers in terms of the degree to which socio-legal content was valued or incorporated into teaching.

The survey also revealed that labour law teachers make use of a variety of socio-legal content, and that they incorporate this material in a variety of ways.

In the next part the following questions are addressed:

(a) What sort of socio-legal materials are incorporated into labour law teaching?

(b) In what ways can socio-legal material be incorporated into labour law teaching? This discussion draws on the survey respondents' views, educational literature and the practice of the author.

(c) How can an appropriate balance be maintained between sociolegal and black letter content?

\section{How Socio-Legal Material Can be Incorporated into Labour LaW TEaching}

\section{A What Sort of Socio-Legal Material is Incorporated into Labour Law Teaching?}

Respondents were asked to identify the categories of socio-legal content used in their courses. As an academic discipline, labour law has, in an Australian and New Zealand context, been strongly affiliated with an industrial relations paradigm which focuses on the mechanisms of collective bargaining. In recent years, this focus has been supplemented, and to an extent displaced, by other paradigms. ${ }^{22}$ Feminist scholarship has also become an increasingly mainstream part of academic labour law discourse. ${ }^{23}$ However, perhaps surprisingly as indicated by the following table, the types of socio-legal material most commonly referred to in undergraduate teaching are the historical and political contexts of the law. Concepts drawn from industrial relations and human resource theory are also frequently mentioned.

22 See generally Richard Mitchell (ed), Redefining Labour Law: New Perspectives on the Future of Teaching and Research (Centre for Employment and Labour Relations Law, 1995) 3-62.

23 For example, the issue of the gendering of the construction of work in law was consciously emphasised and integrated into an Australian text: $\mathrm{R}$ Owens and J Riley, The Law of Work (Oxford University Press, 2007) 16. 
Figure 1: Categories of Socio-Legal Material Frequently Mentioned

\begin{tabular}{lcc}
\hline Answer & Response & $\%$ \\
\hline Historical context & 10 & $91 \%$ \\
Political context & 9 & $82 \%$ \\
$\begin{array}{l}\text { Human resource/industrial relations theories and } \\
\text { concepts; for example, pluralism, human capital, the }\end{array}$ & 8 & $73 \%$ \\
psychological contract & & \\
Economics & 5 & $45 \%$ \\
Political theory & 4 & $36 \%$ \\
Feminist theory & 4 & $36 \%$ \\
\hline
\end{tabular}

One respondent commented:

whilst I find little room for important perspectives (eg feminist theory, aside from osmosis since texts like Owens and Riley are informed by it) I'm reasonably happy in guiding students to think about labour law in its political (both legislative politics, and industrial politics) context.

It is unlikely to be feasible to do full justice in a single undergraduate course to all the possible socio-legal factors which form part of the underlying context of labour law. The author agrees with Doorey when he states: ${ }^{24}$

What we need is a curriculum that will facilitate contextual learning of [labour] law. I am not proposing a specific teaching agenda. Some instructors may stress the historical aspects of labour policy, others the gender, class or race dimensions; others will situate labour policy within a broader discussion of pluralism and the limitations of the state. That's the beauty of the subject; there is no shortage of entry points ... It would be a shame to lose sight of all this and instead simply subject the students to the regurgitation of legal rules set down in statutes and legal decisions.

\section{B How Can Socio-Legal Material Be Incorporated into Teaching?}

It was stated in Part I above that incorporating socio-legal content into labour law can contribute towards creating an environment conducive to deep learning and active learning. By providing opportunities for students to make connections between labour law and its surrounding context, teachers can provide a high quality learning experience which equips students with a wider perspective from which to engage in critical evaluation of the law. There are a

24 Doorey, above n 4, 15-16. 
variety of ways that socio-legal material can be incorporated into labour law teaching. Some, arguably, are more conducive to deep learning than others.

Survey respondents were invited to comment on the ways in which socio-legal content is incorporated into their teaching. As the table below indicates, informal mention in the course of lectures and class discussion, and references to socio-legal material in the assigned compulsory readings, were the most common methods.

Figure 2: How is Socio-Legal Material Incorporated in Teaching?

\begin{tabular}{lcc}
\hline Answer & Response & $\%$ \\
\hline $\begin{array}{l}\text { Informal mention in the course of lectures, } \\
\text { tutorials and general class discussion }\end{array}$ & 9 & $82 \%$ \\
$\begin{array}{l}\text { Assigned compulsory readings } \\
\begin{array}{l}\text { Some component of the assessment (essay, } \\
\text { test, exam) requires students to refer to socio- }\end{array}\end{array}$ & 9 & $82 \%$ \\
$\begin{array}{l}\text { legal concepts and readings } \\
\text { Part of structured discussion in tutorials }\end{array}$ & 6 & $73 \%$ \\
Recommended but not required readings & 4 & $36 \%$ \\
\hline
\end{tabular}

It is notable that, of the 11 respondents who reported that some socio-legal material was incorporated into their labour law teaching, three reported that none of the assessment in the course required students to make any reference to socio-legal material. This is significant because, as stated by Rowntree: ${ }^{2 s}$

If we wish to discover the truth about an education system, we must look to its assessment procedures ... The spirit and style of student assessment defines the de facto curriculum.

Ramsden also states that, '[f]rom our students' point of the view, the assessment always defines the actual curriculum. ${ }^{26}$ This implies that, if the assessment does not require students to make any reference to socio-legal material, de facto socio-legal material does not occupy an important role in the curriculum.

Individual labour law teachers will have their own views as to how important engagement with socio-legal material is within the context of each particular course. This will, no doubt, be influenced by student characteristics and the priorities and framework set by the wider institutions within which each teacher must operate. However,

25 D Rowntree, Assessing Our Students: How Shall We Know Them? (Harper and Row, 1977) 1

26 Ramsden, above n 16, 182. 
for those who view it as very important, this imperative arguably should be reflected in assessment.

Biggs proposes the following design for good teaching, which he summarises simply: ' $[w]$ hen we have decided what we want students to learn, we teach and assess accordingly. ${ }^{27}$ In his view, a good teaching system traps students in a network of higher-order learning activities which he calls 'constructive alignment'. All components in the system must interact. The course objectives must clearly state the kind of understanding that is sought. Teaching and learning activities and assessment must be designed so as to serve these objectives. ${ }^{28}$ In Biggs's view, such a system is conducive to deep as opposed to surface learning..$^{29}$

If socio-legal content is indeed very or somewhat important to the learning of labour law, it should arguably be interwoven throughout the course: in the objectives, the teaching and learning activities chosen, and the assessment. This is the approach which the author has adopted in teaching undergraduate labour law to business students over the past few years. Some key ways in which sociolegal content has been embedded in the course are presented here by way of illustration of what is possible.

The course objectives are as follows:

Students successfully completing this course will be able to demonstrate the ability to:

1. Describe the context of the law perfaining to the employment relationship and the nature of factors affecting the development and possible future direction of the law.

2. State the legal principles governing the employment relationship both at the individual and the collective level.

3. Apply selected areas of the law to individual fact situations.

4. Critically evaluate the legal principles and institutions governing employment relations and if appropriate formulate ideas for law reform. [emphasis added]

In the first lecture, it is clearly signalled to students that, while the majority of the course will focus on practical applied law, there will be one question in the exam which will reflect the objectives in italics (hereafter, the 'socio-legal question'). Students are also reassured that, if they fully engage with the assigned readings in the course materials book, and thoughtfully participate in class and tutorial discussions and exercises, they will be able to satisfactorily answer the question.

27 J Biggs, 'Assessment an Integral Part of the Teaching System' (1999) 51 American Association for Higher Education Bulletin 10, 11.

28 John Biggs, Teaching for Quality Learning at University: What the Student Does (Open University Press, 1999) I1-33

29 Biggs, 'Assessment an Integral Part of the Teaching System', above n 27, 12. 
Students are guided towards how they might answer the sociolegal question throughout the course by explanations of socio-legal material during lectures, assigned readings, and in class tutorial discussions. For example, in the first tutorial, two readings on the Employment Relations Act 2000 (NZ) are assigned. One is by Professor Margaret Wilson, who was essentially the architect of the Act. The other is by a representative of the Employers Association, which was very much opposed to the Act. The first two tutorial questions require students to go through the readings and identify the rights-based and economic arguments each is making in support of their views. The final question asks students to conclude by explaining which argument they agree with.

This tutorial is intended to make it clear to students that a range of perspectives exist on the various topics, as well as to encourage them to reflect on their own ideas in the light of these perspectives. It is designed to scaffold learning by a process of gradually building students' confidence, both in terms of their knowledge of the readings and associated concepts, and their ability to formulate their own informed views.

The tutorial typically runs as follows: at the beginning of the class, students are generally unprepared and unwilling to participate. They are split into groups of five or six students with each group assigned a portion of an article to analyse. They are instructed that they must work together to identify the economic and rights-based arguments in their assigned part of the text. Each group reports back to the class as a whole. Findings are written up on the whiteboard in the form of a table with arguments for and against the Employment Relations Act 2000 (NZ). By the end of the class, most of the students are actively participating and everybody is sufficiently engaged to come up with some conclusion on which arguments they agree or disagree with. (Most choose to disagree with both.) The tutorial is successful, because it begins by asking students to do a basic analysis of a relatively small piece of text in an unthreatening situation. It then builds to a point where, by the end of the tutorial, they begin to feel some confidence in their abilities to form and express their own views.

This is an example of the socio-legal question in one exam:

Some key factors in the underlying social, economic and political environment and context that have shaped labour and employment law in New Zealand are:

a) Shifting perceptions of where the balance of power lies; and

b) Different economic theories; and

c) Decline in unionisation; and

d) Different ways of organising work; and

e) More women participating in the work force; and

f) Globalisation. 
Discuss how any TWO, or more, of the above key factors have contributed to the current state of labour and employment law in New Zealand and how these factors may affect the law in the future.

This question requires students to connect key concepts in the underlying socio-legal environment to the development of the substantive law the course has covered. Students were given a general indication of what the question would cover in advance and instructed that they should refer to the readings in their course book to answer the question. The readings in the course book ranged from a feminist perspective on work, to discussions of various labour market theories. Giving students a choice about which two underlying factors they focused on was intended to allow them the scope to focus on what they found most of relevance and interest and so to develop their own views. A more conservative student had the option of focusing on the economic arguments surrounding labour market regulation and globalisation. A more left leaning liberal student could choose to consider international human rights regimes and the status of women's work.

This is another example of the socio-legal question in another exam:

The legal status of 'employee' is a prerequisite of accessing rights to statutory minimum entitlements such as the minimum wage, rights to personal grievances and the right to collectively bargain under the Employment Relations Act.

A bill is currently being considered by a Select Committee which, if passed, will amend the Employment Relations Act definition of employee as follows:

Meaning of employee

(1) In this Act, unless the context otherwise requires, employee -

(a) means any person of any age employed by an employer to do any work for hire or reward under a contract of service; ...

(2) In deciding for the purposes of subsection (1)(a) whether a person is employed by another person under a contract of service the Authority or Court must treat as a determining matter any statement by the persons that describes the nature of their relationship.

Write a submission to the Select Committee. Your submission may be either in support of, or against the proposed amendment, or you could propose an alternative amendment.

Your answer should include:

(i) Consideration of the objectives of the Employment Relations Act

(ii) Any other factors you consider to be important

The process of marking answers to the socio-legal question is instructive. Over the years, the author has observed that not all students answer the question satisfactorily. In particular, students 
who fail to attend class struggle with it. However, it has also been heartening to observe that a number of students show evidence of thoughtful reflection, originality and passionate conviction in their answers the question. The course is a work in progress, and it is possible that the socio-legal question would be better answered outside of an exam situation where there would be more time for thoughtful reflection. This may be attempted in years to come; however, this will have to be balanced against the need to ensure that students receive a suitable grounding in black letter law. This tension is one that other labour law teachers feel constrained by, as discussed below.

Overall, course evaluations and feedback from students have been very positive. In a recent evaluation, the majority of students strongly agreed with the statement that the teacher stimulated their interest; strongly agreed with the statement that the course was well organised; and strongly agreed with the statement that students felt respected in the class.

Some individual comments are as follows:

[T]he learning environment encouraged me to think for myself rather than regurgitate the lecturer's view.

[R]eadings well chosen and enabled us to critique the legal system with confidence.

\section{The Importance of Striking a Balance between Socio-Legal and Non-Socio-Legal Content}

While a case has been made here for incorporating some sociolegal material into labour law teaching, just how much time should be spent on socio-legal content remains an open question. When survey respondents were asked to estimate what percentage of teaching time they spent on socio-legal content, their answers ranged from 10 to 60 per cent, with a mean of 25 per cent.

Two respondents implied that, while they would like to introduce more socio-legal material into their teaching, the volume and complexity of legislation and case law precludes this. One respondent stated:

Unfortunately the growth of legislation and case law in both volume and complexity has limited my ability to use contextual material more extensively.

Another respondent stated:

I fear what I do is fairly superficial; but then the course is just an 'introductory elective'. It would be nice to do more but the legislation is so dense these days, and there are challenging, practical black letter content and skills to introduce students to (such as reading tribunal as opposed to court decisions; tackling awards and collective agreements). 
These teachers evidently see a place for socio-legal content and a 'Pericles' approach to teaching labour law, but they raise a key challenge.

In practice, the optimal mix and balance of socio-legal material versus black letter law content is likely to vary, depending on the nature and level of the course and the students enrolled in it. This study focused on introductory undergraduate courses and it could be expected that postgraduate courses would have more scope for socio-legal analysis.

Another important insight was as follows:

Student response to SL content is quite mixed, I think, especially if it gets much beyond $20 \%$.

This is in keeping with Doorey's observation on the persistent ongoing tension in legal pedagogy between teaching law as a vocation or as broader liberal art. He notes that:

Based on conversations with students, reading evaluations, and speaking with other ... teachers over the years, my sense is that students ... prefer the more practical vocational components of the courses over the broader theoretical and multi- disciplinary subject matter. ${ }^{30}$

The author has also seen some evidence of this view among certain students. For example, one student commented on a course evaluation form that they would have preferred 'less history, more personal grievances'.

The above comments suggest that care must be taken in presenting socio-legal material. Student motivation, interest and perception of the relevance of the curriculum must necessarily affect learning outcomes. Indeed, it is Ramsden's first key principle of effective teaching in higher education that good teaching must stimulate student interest. ${ }^{31}$ If students perceive that the material they are presented with is extraneous and irrelevant, this will result in disengagement rather than the deep and active learning previously identified as desirable.

Student disengagement is not, however, inevitable. According to Ramsden, student engagement and deep learning are encouraged by teaching which 'demonstrates the lecturer's personal commitment to the subject matter and [which] stresses its meaning and relevance to students. $^{232}$

This suggests that, if possible, the socio-legal content selected for inclusion in the course should align with the lecturer's own interests. Educational research has suggested repeatedly that the teachers who students find most engaging are those who convey passion and

30 Doorey, above a $4,22$.

31 Ramsden, above $\mathrm{n} 16,96$.

32 Ibid 80. 
enthusiasm for the subject matter. ${ }^{33}$ Lecturers should also explicitly stress the meaning and relevance of socio-legal content to students. ${ }^{34}$ One obvious way to do this, in an Australian and New Zealand context, would be to point to the rapid pace of change in law and hence the futility of focusing solely on acquiring detailed technical knowledge which may very soon become obsolete.

\section{$\mathrm{V}$ CONCLUSION}

There appears to be a gap between the apparent consensus in the literature that socio-legal material is a necessary part of labour law teaching and the practice of at least some of those who teach labour law. As indicated by the survey, some labour law teachers exclude any material of a socio-legal nature from their course altogether.

Here, it has been suggested that there are reasons for labour law teachers to consider incorporating some reference to socio-legal material in their teaching. This would, of course, need to be balanced against the very real need to cover a certain amount of black letter content. As a corollary, it should be noted that the amount of sociallegal material which should be incorporated, and how this should be done in an introductory undergraduate course, are open questions. It has been argued here that some reference to socio-material is desirable to fulfil the objectives of developing intellectual independence in the context of the universities' role as conscience and critic as well as fostering deep and active learning. It is possible that these goals are adequately served, at least in introductory undergraduate courses, by informal references to socio-legal material in lectures and through assigned readings. However, if it is indeed very important that students should learn to see the law in its socio-legal context, this should ideally be stated as a formal course objective, interwoven into the curriculum and reflected in assessment.

\footnotetext{
33 Ibid 72.

34 Ibid 74 .
} 


\section{APPENDIX A: QuestionNAire (ABBREVIATED)}

1. If you are involved in teaching labour law to undergraduate students, are these students undergraduate business students/ undergraduate law students?

2. A wide variety of material may defined as socio-legal content in context of teaching the labour law. Broadly, here, it may be understood as any content which is not doctrinal black letter law; such as, for example, the historical or political context of the law, economics, political theory, feminist theory, or concepts drawn from industrial relations and human resources.

Is there any reference, whether formally or informally, to sociolegal content in the course you are focusing on for the purposes of this questionnaire? Which categories does the socio-legal content referred to in the course fit within?

3. How is socio-legal content incorporated in the course?

4. Approximately what percentage of teaching time is spent on socio-legal content?

5. Approximately what percentage of your assessment (essays, questions in tests and exams, etc) requires students to refer to socio-legal content?

6. How important do you think it is to refer to socio-legal content in teaching labour law? 